\title{
EKSPLORASI SUMBER IMAJINASI MAHASISWA TENTANG PROFESI DOKTER
}

\author{
Yoga Pamungkas Susani*, Gandes Retno Rahayu**, Rossi Sanusi**, Yayi Suryo Prabandari**, Harsono** \\ * Fakultas Kedokteran, Universitas Mataram \\ ** Bagian Pendidikan Kedokteran, Fakultas Kedokteran, Universitas Gadjah Mada
}

\begin{abstract}
Background: In the process of becoming a doctor, a medical student experiencing the development of professional identity. In this process, students need a broad picture of medical profession. They need to orient themselves in the medical profession to determine the future professional identity as a doctor. Source of the picture of medical profession needs to be explored further. This study aims to explore the ways students get picture of the medical profession.
\end{abstract}

Method: Qualitative research by conducting in-depth interviews to 17 preclinical and clinical medical students. Determinants and emergent coding performed to analyze the results of the interview.

Results: Source of imagination can be derived from the curriculum and outside the curriculum. Students get two important things, first was overview of the work environment and how the physician work and second was physician professional values. Characters of role models identified primarily from student interaction with faculties. The characters include faculty's role as teacher, as doctor, their personal atributes and how they interact with students.

Conclusion: Formal curriculum plays important roles in providing and facilitating students to get overview about the work environment and how the doctors work in the health service. Although the transfer of professional value to students is determined by the hidden curriculum, but the formal curriculum can facilitate by providing activities that allows the interaction between generations or conduct review on fiction and non-fiction medical stories and histories that is obtained from media.

Keywords: imagination, identity, professional identity, hidden curriculum, role model, formal curriculum, participation

\section{ABSTRAK}

Latar belakang: Dalam proses menjadi dokter, seorang mahasiswa kedokteran mengalami proses tumbuhnya identitas profesional dokter. Perkembangan identitas merupakan proses negosiasi dalam diri yang bersifat dinamis. Dalam proses tersebut mahasiswa memerlukan gambaran tentang profesional dokter untuk dapat mengorientasikan dirinya dalam komunitas profesi dokter dan menentukan identitas profesionalnya kelak sebagai dokter. Sumber gambaran tersebut perlu dieksplorasi lebih jauh. Penelitian ini bertujuan untuk mengeksplorasi cara-cara mahasiswa mendapatkan gambaran tentang profesi dokter.

Metode: Penelitian kualitatif dengan melakukan wawancara mendalam kepada 17 mahasiswa kedokteran preklinik dan klinik. Koding determinan dan emergent dilakukan untuk menganalisis hasil wawancara.

Hasil: Sumber imajinasi dapat berasal dari kurikulum maupun dari luar kurikulum. Mahasiswa mendapatkan 2 hal penting, yaitu 1) gambaran tentang lingkungan dan cara kerja dokter; 2) nilai profesional dokter. Karakterkarakter role model dari dosen teridentifikasi terkait perannya dalam pengajaran, peran sebagai dokter, atribut personal sehari-hari dan dalam berinteraksi dengan mahasiswa.

korespondensi: yoga_pamungkas_s@yahoo.com 
Kesimpulan: Kurikulum formal sangat berperan penting dalam memberikan gambaran kepada mahasiswa tentang lingkungan dan cara kerja dokter dalam pelayanan kesehatan. Meskipun transfer nilai profesional kepada mahasiswa sangat ditentukan oleh kurikulum tersembunyi, namun kurikulum formal dapat membantu memfasilitasi dengan menyediakan aktivitas yang memungkinkan terjadinya interaksi dokter antar generasi atau melakukan telaah-telaah terhadap cerita fiksi dan non fiksi yang didapat dari berbagai media.

Kata kunci: imajinasi, identitas profesional, role model, kurikulum tersembunyi, kurikulum formal, partisipasi

\section{PENDAHULUAN}

Perkembangan identitas professional adalah topik yang sedang berkembang dan menjadi perhatian di bidang pendidikan kedokteran. Bagi mahasiswa kedokteran, identitas profesional adalah suatu kondisi internal yang diperoleh dan dibentuk selama pendidikan kedokteran. ${ }^{1}$ Hilton dan Slotnick ${ }^{2}$ menggunakan istilah proto-professionalism untuk mewakili proses pembentukan identitas profesional selama dalam pendidikan. Proto-professionalism merupakan proses pengembangan identitas, yaitu yang dilakukan seseorang dan caranya dalam berinteraksi dengan yang lainnya. Forsythe ${ }^{3}$ menyebutkan bahwa kompetensi profesional memang penting, namun memiliki perasaan "who they are" akan berpengaruh pada "how they practice". Cara mahasiswa mengkonseptualisasi dan mengembangkan identitas profesional akan berimplikasi pada kehidupan profesionalnya kelak dalam cara berinteraksi dengan rekan kerja ataupun pasiennya. Mengingat pentingnya identitas profesional, fakultas perlu memahami proses pembentukan identitas profesional dalam diri mahasiswa. Hal tersebut akan memberikan panduan untuk merancang pembelajaran dan lingkungan pendidikan yang mampu memfasilitasi proses tersebut. ${ }^{4}$

Identitas profesional merupakan salah satu bentuk dari identitas sosial. Identitas sosial adalah pengetahuan seseorang bahwa dirinya termasuk dalam suatu kelompok atau kategorisasi. ${ }^{5}$ Kelompok sosial adalah seperangkat individu yang memegang identifikasi sosial umum atau pandangan diri mereka sebagai anggota dari kategori sosial yang sama. Identitas sosial dapat didefinisikan ke dalam berbagai dimensi, dalam hal ini adalah dimensi profesional. Identitas profesional merupakan integrasi antara nilai, perilaku, keterampilan dan pengetahuan yang dibagikan antar anggota kelompok profesi dan digunakan untuk membedakan antara anggota kelompok dan bukan anggota kelompok. Identitas yang terbentuk akan menentukan cara kerja mahasiswa kelak dalam dunia profesi.

Proses perkembangan identitas profesional membutuhkan partisipasi dalam komunitas profesi tersebut. Menurut Wenger, ${ }^{6}$ partisipasi merupakan proses belajar. Partisipasi dapat dilakukan dalam 3 bentuk modes of belonging ${ }^{6}$ atau modes of identification? Hal tersebut karena partisipasi merupakan aktivitas yang menumbuhkan rasa memiliki dan menjadi sarana untuk melakukan identifikasi. Modes of identification meliputi keterlibatan, imajinasi dan kesesuaian. Keterlibatan merupakan suatu aksi yang dilakukan sendiri atau bersama, diskusi bersama, menggunakan atau menghasilkan suatu artefak. ${ }^{7}$ Imajinasi membangun pandangan tentang diri, tentang komunitasnya, dan tentang dunia luar untuk dapat mengorientasikan diri, merefleksikan situasi dan mengeksplorasi kemungkinan. Kesesuaian merupakan proses memilih dan membentuk komitmen. Partisipasi yang dilakukan sesuai dengan konsep atau prinsip yang dipegang oleh komunitas tersebut, dan dapat meyakinkan bahwa aktivitas lokal tersebut juga sesuai dengan proses lain yang dapat diterima secara global.

Salah satu bentuk partisipasi yang penting adalah imajinasi. Imajinasi dalam hal ini bukan fantasi, tetapi cara seseorang mengorientasikan dirinya terhadap lingkungannya. ${ }^{7}$ Selama masa pendidikan, mahasiswa mengidentifikasi kesempatan dan alternatif yang ditawarkan oleh profesi dan pada akhirnya berkomitmen terhadap nilai dan tujuan profesional yang dianggap penting oleh mereka. 
Untuk dapat berimajinasi, mahasiswa memerlukan paparan dan gambaran selengkapnya tentang profesi dokter. Fakultas perlu menyediakan lingkungan yang dapat memberikan gambaran tentang profesi dokter atau memfasilitasi terbentuknya imajinasi mahasiswa tentang diri dan profesi dokter. Penelitian ini bertujuan untuk mengeksplorasi sumber imajinasi mahasiswa tentang profesi dokter.

\section{METODE}

Penelitian ini merupakan bagian dari penelitian fenomenologi yang bertujuan menggali arti pengalaman belajar mahasiswa selama menjalani pendidikan kedokteran. Penelitian dilakukan di Fakultas Kedokteran Universitas Gadjah Mada. Penelitian telah mendapat ijin dari fakultas dan telah mendapat ethical clearance dari komite etik FK UGM.

Pengambilan data dilakukan dengan melakukan wawancara mendalam semi terstruktur kepada 17 mahasiswa yang terdiri dari 9 mahasiswa preklinik tahun 1, 2, 3 dan 8 mahasiswa klinik tahun 1 dan 2 rotasi klinik. Pengambilan sampel dilakukan dengan mempertimbangkan proporsi variasi jenis kelamin, indeks prestasi kumulatif, dan keaktifan dalam organisasi.

Wawancara dilakukan oleh peneliti menggunakan panduan wawancara yang telah diuji cobakan. Pertanyaan utama dalam menggali sumber imajinasi adalah: darimana Anda mendapatkan gambaran tentang dokter profesional? Selanjutnya digali kembali terkait role model, tokoh kedokteran, dan sumber imajinasi lainnya.

Koding terbuka dilakukan terhadap transkrip hasil wawancara. Koding dilakukan oleh peneliti dan 1 orang koder independen yang lain untuk meningkatkan trustworthiness analisis. Sebelumnya, persepsi para koder terhadap cara koding disamakan. Masing-masing koder secara independen menganalisis hasil wawancara. Kedua koder kemudian bertemu untuk menilai hasil koding dan membuat kesepakatan pada kode-kode yang berbeda. Selain dengan multicoder, untuk meningkatkan kepercayaan pada data, dilakukan member checking. Member checking dilakukan dengan memberikan hasil transkrip asli, koding, dan interpretasi umum peneliti terhadap hasil wawancara kepada mahasiswa melalui email. Mahasiswa telah memberikan persetujuan secara langsung maupun melalui email. Hasil kode selanjutnya dikelompokkan dalam kategori-kategori.

\section{HASIL DAN PEMBAHASAN}

Data dikategorisasikan ke dalam jenis sumber gambaran dan manfaat yang didapatkan. Jenis sumber gambaran dapat berasal dari pembelajaran kurikulum dan sumber gambaran di luar pembelajaran kurikulum (Gambar 1). Sumber imajinasi yang berasal dari pembelajaran tidak hanya langsung dari kurikulum formal yang memang direncanakan oleh fakultas, namun juga tidak langsung dari pengamatan mahasiswa selama menjalankan aktivitas formal tersebut. Inilah peran kurikulum informal dan tersembunyi.

Pada Gambar 1 terlihat bahwa dalam kurikulum formal, fakultas menyediakan aktivitas-aktivitas yang membantu mahasiswa untuk mendapatkan gambaran tentang profesi dokter. Hal ini meliputi penugasan ke masyarakat ataupun pusat layanan kesehatan (puskesmas, rumah sakit), pembelajaran di skills lab yang memberikan seting seperti praktik dokter, dan program pendidikan klinik. Mahasiswa tingkat sarjana mendapatkan gambaran tentang lingkungan kerja dan cara kerja dokter dalam pelayanan kesehatan dari pengalaman mereka ketika ditugaskan untuk melakukan observasi di pusat layanan kesehatan. Pembelajaran di skills lab tidak hanya memberikan gambaran tentang seting klinik, namun juga menumbuhkan perasaan sebagai dokter ketika mereka melakukan simulasi manajemen pasien. Aktivitas-aktivitas tersebut secara langsung dapat menjadi sumber gambaran mahasiswa untuk dapat mengorientasikan dirinya dalam profesi dokter. Hal ini dapat terlihat dari kuotasi mahasiswa berikut:

"ee.. mungkin dari salah satu kegiatan ini ya apa yang datang ke puskesmasitu, hari sabtu. menurut saya juga sa sarana yang bagus untuk mendekatkan ee..dunia klinisi dengan dunia akademis seorang mahasiswa untuk melihat ee.. pekerjaan seorang dokter itu nanti seperti apa" 12 ALIPT 4 [14893:15552] 


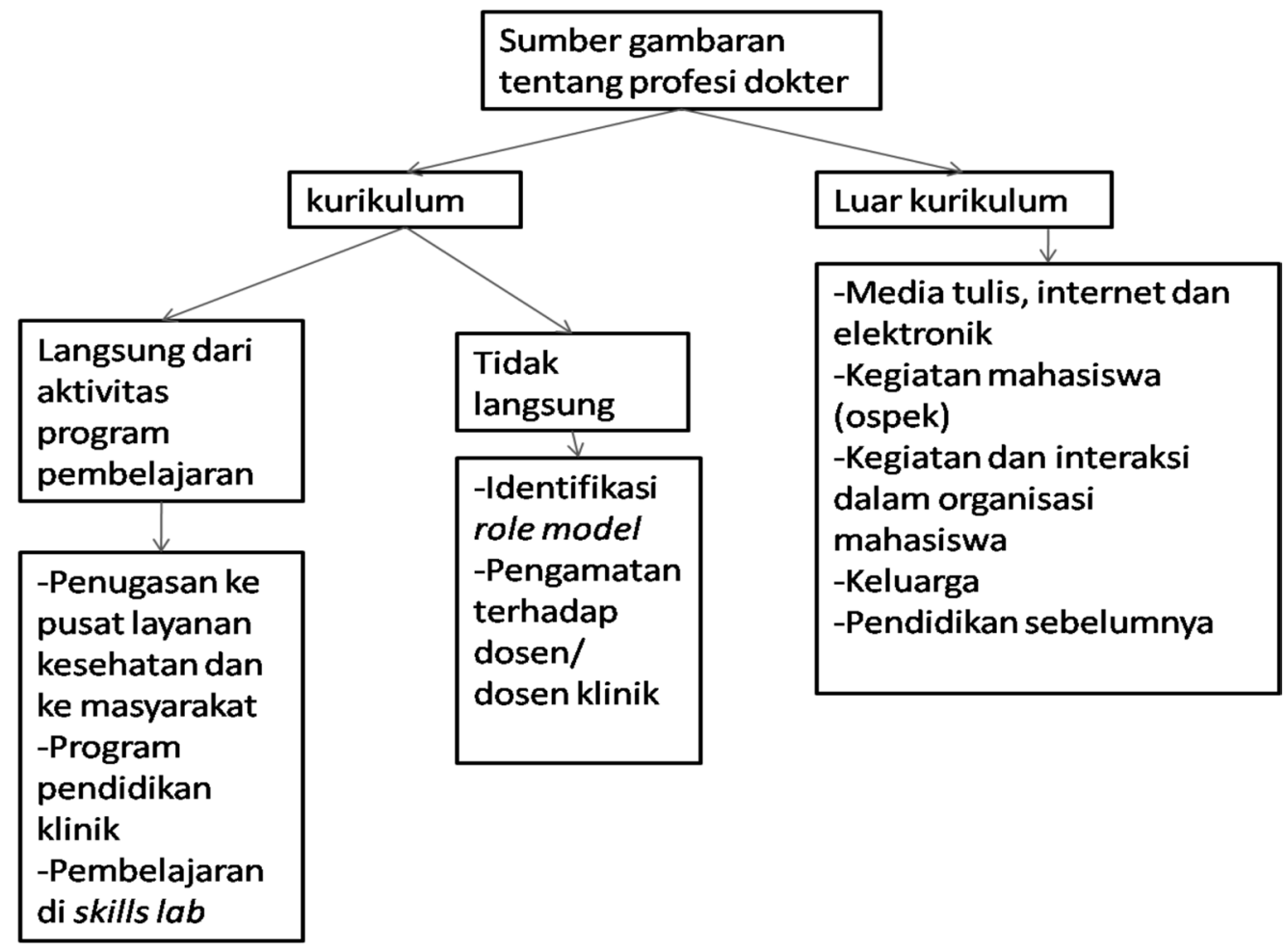

Gambar 1. Pengelompokan sumber gambaran tentang profesi dokter

Pada Gambar 1 juga terlihat bahwa mahasiswa juga mendapatkan gambaran secara tidak langsung dari mengikuti program pembelajaran dalam kurikulum. Dalam hal ini mahasiswa menangkap nilai dari kurikulum tersembunyi. Mahasiswa secara tidak langsung mengamati dan menyerap hal-hal yang mereka lihat sehari-hari. Mahasiswa dapat mengidentifikasi role model mereka, mengidentifikasi sifat yang baik dan buruk pada dosen, dokter atau perawat.

Mahasiswa memerlukan sosok dokter klinik sebagai panutan. Mahasiswa tingkat sarjana mendapatkan role model terkait dengan pengajaran, namun masih minim mendapat role model klinik. Dari partisipan tahun ke-1 hingga 5 didapatkan bahwa mereka dapat mengidentifikasi sosok dokter panutan dalam perannya sebagai dokter klinik adalah ketika menjalani pendidikan klinik. Kuotasi berikut ini didapatkan dari mahasiswa tahun ke-2, yang menunjukkan bahwa mahasiswa tersebut belum menemukan sosok dokter panutan dan belum dapat memberikan gambaran tentang dokter profesional.

X : Kalau menurut Anda seperti apakah sosok dokter yang profesional?
Y : "emmm mungkin gimana ya, habisnya belum ada sih, belum pernah ketemu."

$\mathrm{X}$ : belum pernah ketemu?

$\mathrm{Y}$ : "he eh. Habisnya tiap dokter pasti ada kurangnya. Ya nggak ada yang sempurna sih. tapi ada di satu sisi misalnya nemu dokter yang kadang dia moody, jadi kalau dia moodnya lagi baik anak-anak pada mau ketemu, waa dia lagi baik loh moodnya, ketemu. Trus cerita apa, sharing apa gini gini. Kalau misalnya lagi moodnya lagi jelek stop dulu gitu. Nggak, nggak bakal nanya-nanya tentang apa, cerita tentang apa gitu-gitu. Trus ada juga dokter yang ramah banget, ada. Tapi di satu sisi tuh kadang keramahanya malah diiniin sama tementemen, jadi digimanain ya, belum ada gitu, masih bingung jadinya yang..."

X : Kalau besok ingin menjadi dokter yang seperti apa?

Y : " "emmm paling nggak ya yang kayak gimana ya? Bingung. Ada option nggak dok?"

10-APIPR-2 [ 8991: 9834] 
Eksplorasi tentang role model menghasilkan pengelompokan karakter dosen yang dianggap sebagai role model oleh mahasiswa. Tabel 1 menunjukkan karakter-karakter dosen dalam hal mengajar, dalam berperan sebagai dokter, dalam perilaku seharihari yang tampak, dan dalam berinteraksi dengan mahasiswa.

Tabel 1. Karakter Dosen Sebagai Role Model

\begin{tabular}{|c|c|c|c|}
\hline \multicolumn{4}{|c|}{ Karakter dosen sebagai role model } \\
\hline Dalam pengajaran & Sebagai dokter & Sikap perilaku & $\begin{array}{l}\text { Sikap terhadap } \\
\text { mahasiswa }\end{array}$ \\
\hline $\begin{array}{l}\text { - Antusias berbagi ilmu } \\
\text { - Semangat mengajar } \\
\text { - Tidak terkesan sekedar } \\
\text { menjalankan tugas } \\
\text { - Mudah diajak berdiskusi } \\
\text { - Atraktif, humoris } \\
\text { - Komunikatif } \\
\text { - Interaktif } \\
\text { - Kompeten, menguasai } \\
\text { materi } \\
\text { - Cara mengajar baik, } \\
\text { penyampaian baik, mudah } \\
\text { dimengerti } \\
\text { - Tidak tegang } \\
\text { - Detail } \\
\text { - Wawasan luas } \\
\text { - Memberikan umpan balik } \\
\text { dengan baik } \\
\text { - Komitmen mengajar } \\
\text { - Motivator }\end{array}$ & $\begin{array}{l}\text { - Mengutamakan pasien } \\
\text { - Komitmen tinggi terhadap } \\
\text { profesi } \\
\text { - Selalu memperbaharui } \\
\text { (update) ilmu } \\
\text { - Etika baik } \\
\text { - Penanganan pasien secara } \\
\text { holistik } \\
\text { - Altruis } \\
\text { - Kompeten } \\
\text { - Pendekatan ke pasien baik } \\
\text { - Mampu mengedukasi } \\
\text { pasien dengan baik } \\
\text { - Menghormati pasien } \\
\text { - Komunikatif } \\
\text { - Peduli terhadap masalah } \\
\text { kesehatan dan kebijakan }\end{array}$ & $\begin{array}{l}\text { - Ramah } \\
\text { - Tegas } \\
\text { - Tanggung jawab } \\
\text { sosial tinggi } \\
\text { - Sederhana } \\
\text { - Pandai } \\
\text { - Rendah hati } \\
\text { - Sabar } \\
\text { - Disiplin } \\
\text { - Terbuka } \\
\text { - Manajemen waktu } \\
\text { baik } \\
\text { - Tulus }\end{array}$ & $\begin{array}{l}\text { - Dekat dengan } \\
\text { mahasiswa } \\
\text { - Perhatian } \\
\text { - Menghormati } \\
\text { mahasiswa }\end{array}$ \\
\hline
\end{tabular}

Dari luar kurikulum, mahasiswa mendapatkan gambaran profesi dokter dari media, kegiatan organisasi kemahasiswaan, keluarga tenaga kesehatan (dokter, perawat, bidan, ahli farmasi), pengalaman diri atau keluarga menjadi pasien. Dari media, mahasiswa ada yang senang membaca buku tentang dokter nyata maupun fiksi, bahkan komik, melihat film berlatar belakang kedokteran. Mahasiswa mengenal tokohtokoh kedokteran dari pendidikan sebelumnya dan dari kegiatan ospek (orientasi mahasiswa di awal masuk fakultas kedokteran). Selanjutnya mahasiswa tidak mendapatkan pembelajaran tentang tokoh kedokteran.
X : Apa yang didapatkan dari membaca buku tersebut?

Y : " $\quad$ di dapatnya lebih ke pengalaman, jadi lebih ke gambaran ketika di daerah seperti ini, apa yang ada dilapangan mulai dari penunjangnya seperti apa kemudian sikap masyarakatnya seperti apa, ya itu yang selama ini kami belum pernah merasakan di sini di pendidikan seperti ini, ya itu juga di dapatkan sehingga temen temen kalo udah selese dari sini kelapangan udah siap gambaran gambaran kayak tadi itu.” 
Kegiatan organisasi mahasiswa membawa mahasiswa berinteraksi lebih luas dengan masyarakat dan membuka kesempatan mahasiswa untuk terlibat dalam kegiatan sosial. Selain itu kegiatan organisasi memungkinkan mahasiswa berinteraksi saling bertukar cerita dan pengalaman terkait profesi dokter.

Tabel 2. Sumber dan Gambaran Tentang Dokter yang Didapatkan

Sumber

Media

\section{Jenis}

Komik (medical dragon, good enteru,

dr. Koto)

Film (greys anatomy, dr house, miami,

ER, scrub, 3idiots, dll)

Buku (the doctors, kisah

pengalaman dokter)

Majalah

Media elektronik (berita televisi,

radio)

Media internet (koas racun,

komunitas di sosial media)

\section{Yang didapatkan}

Gambaran praktik di masyarakat, di daerah terpencil

Memberi gambaran tentang penanganan pasien; tips-tips dalam praktik

klinis

Membantu mengingat materi kuliah

Mengenal berbagai macam karakter dokter; mengenal konflik-konflik

dalam praktik

Mendapat inspirasi, motivasi, pelajaran hidup

Mendapat gambaran tentang kehidupan dokter (sosial, pribadi)

Mendapat gambaran tentang pandangan masyarakat terhadap profesi

dokter, kebijakan di bidang kesehatan

Mengajarkan nilai professional (santun, dekat dengan masyarakat,

ramah, komitmen)

Mengenal organisasi-organisasi medis di dunia Mendapat gambaran tentang pendidikan klinik

\begin{tabular}{|c|c|c|}
\hline Orientasi & Orientasi (ospek) & Mengenalkan tokoh kedokteran terkait FK UGM; Sejarah FK UGM \\
\hline $\begin{array}{l}\text { Pembelajaran } \\
\text { dari kurikulum }\end{array}$ & $\begin{array}{l}\text { Pembelajaran dalam kurikulum, } \\
\text { skills lab } \\
\text { Pengalaman partisipasi (kunjungan } \\
\text { ke pusat pelayanan kesehatan) } \\
\text { Kegiatan sehari-hari di koas }\end{array}$ & $\begin{array}{l}\text { Cara kerja praktik dokter di berbagai seting } \\
\text { Sistem manajemen rumah sakit } \\
\text { Cara kerja profesi lain yang terlibat dalam pusat pelayanan kesehatan } \\
\text { Melihat perbedaan antara kenyataan dengan yang seharusnya } \\
\text { Sistem manajemen pembayaran }\end{array}$ \\
\hline $\begin{array}{l}\text { Pengalaman di } \\
\text { luar kurikulum }\end{array}$ & $\begin{array}{l}\text { Membantu praktik tenaga } \\
\text { kesehatan } \\
\text { Pengalaman merawat keluarga }\end{array}$ & Merasakan tanggung jawab sebagai dokter \\
\hline Observasi dosen & $\begin{array}{l}\text { Melihat dosen mengajar/ menjadi } \\
\text { instruktur } \\
\text { Interaksi dosen-pasien }\end{array}$ & Role model, cara bicara, cara mengajar, kompetensi dokter \\
\hline Keluarga & Keluarga tenaga kesehatan & Cara kerja dokter di seting praktik pribadi \\
\hline $\begin{array}{l}\text { Pendidikan } \\
\text { sebelumnya }\end{array}$ & $\begin{array}{l}\text { Paparan sejarah dalam pendidikan } \\
\text { sebelumnya }\end{array}$ & Mengenal tokoh dokter \\
\hline Refleksi & $\begin{array}{l}\text { Refleksi dari kunjungan praktik } \\
\text { lapangan }\end{array}$ & $\begin{array}{l}\text { Ketidaksesuaian kenyataan dengan yang seharusnya; Hambatan untuk } \\
\text { praktik profesional }\end{array}$ \\
\hline Interaksi & $\begin{array}{l}\text { Interaksi dengan dokter; Cerita } \\
\text { dari kakak angkatan }\end{array}$ & Mengenal berbagai karakter dokter \\
\hline
\end{tabular}

Berimajinasi dalam proses perkembangan identitas profesional merupakan cara seseorang untuk mengorientasikan dirinya. Wenger ${ }^{6}$ memberikan contoh 2 orang yang melakukan hal yang sama, yaitu memecah batu, memiliki jawaban yang berbeda ketika ditanya tentang yang mereka lakukan.
Pemecah batu pertama menjawab bahwa ia sedang memecah batu dan membentuknya menjadi persegi, sedangkan pemecah batu kedua menjawab bahwa ia sedang membangun katedral. Pemecah batu kedua memahami tujuannya memecah batu. Ia mengorientasikan dirinya sebagai orang yang 
berperan penting dalam membangun katedral. Dua mahasiswa yang sedang membaca buku kedokteran, mungkin saja memiliki orientasi yang berbeda dengan yang dilakukannya. Lingkungan pendidikan perlu memfasilitasi mahasiswa untuk dapat mengorientasikan diri sebagai seorang dokter profesional kelak.

Hasil penelitian ini memberikan gambaran tentang sumber imajinasi mahasiswa tentang profesi dokter. Jika dikelompokkan, ada 2 gambaran besar yang didapatkan mahasiswa, yaitu lingkungan dan cara kerja dokter serta nilai profesional seorang dokter. Lingkungan dan cara kerja dokter didapatkan terutama dari kurikulum ketika mahasiswa ditugaskan ke pusat layanan kesehatan. Kurikulum memfasilitasi mahasiswa untuk dapat mengobservasi sekaligus menganalisis cara kerja dalam pelayanan kesehatan, mulai dari pelayanan langsung ke pasien hingga tingkat manajemen.

Hal penting kedua yang didapatkan adalah nilai profesional dokter. Nilai ini didapatkan terutama dari yang mereka lihat sehari-hari. Hal ini sejalan dengan pernyataan bahwa kurikulum informal dan tersembunyi dalam pendidikan dokter memegang peranan lebih penting dalam pembentukan identitas profesional. ${ }^{8-13}$ Dalam kurikulum tersembunyi inilah mahasiswa dapat menyerap nilai yang baik maupun yang buruk dalam menjalankan profesi dokter, termasuk dalam hal ini adalah mendapatkan sosok panutan atau role model.

Dalam ilmu pendidikan, kehadiran role model dalam interaksi sosial menjadi salah satu penentu dalam pembelajaran profesionalisme dan perkembangan identitas. Role model merupakan bagian dari hidden curriculum atau kurikulum tersembunyi, yang merupakan representasi aspek-aspek dalam kurikulum yang tidak dapat teridentifikasi dalam kurikulum formal maupun informal. ${ }^{14}$ Yang mahasiswa lihat atau dapatkan akan menentukan siapa mereka dan menjadi dokter yang seperti apa dalam menjalankan profesi dokter kelak. Hal ini dikarenakan identitas dibentuk oleh diri melalui halhal yang sering dijumpai dan yang jarang dijumpai. Seseorang mendefinisikan dirinya dari hal-hal yang familiar, yang diketahui, yang dapat dinegosiasi, dan dapat berguna. Identitas bukan suatu yang tetap namun bersifat dinamis. Identitas merupakan hasil negosiasi arti pengalaman hidup terhadap rasa memiliki ataupun tidak memiliki. ${ }^{7}$ Identitas merupakan pengalaman hidup yang dinegosiasikan dalam diri. Seorang individu mendefinisikan diri dengan cara menyelami pengalaman hidup melalui partisipasi dalam kelompok atau komunitasnya.

Dosen merupakan orang yang berinteraksi langsung dengan mahasiswa. Mahasiswa mendapatkan role model dari dosen ketika mereka melihat dosen mengajar, berinteraksi dengan pasien, menangani kasus pasien, berdiskusi, maupun perilaku yang tampak sehari-hari. Role model yang efektif bersifat multi faktor. Proses tersebut melibatkan keterampilan mengajar yang baik, keahlian dalam keterampilan klinik, dan atribut personal. Proses ini juga melibatkan proses menunjukkan attitude antara lain: entusiasme, menghargai, kesenangan bekerja, dan keseimbangan antara kehidupan profesional dan personal. ${ }^{14} \mathrm{Hal}$ ini sejalan dengan hasil penelitian ini yang juga mengidentifikasi role model dalam pengajaran, dalam praktik klinik, dalam kehidupan sehari-hari (atribut personal) dan dalam berinteraksi dengan mahasiswa. Mahasiswa juga mengidentifikasi karakter dosen yang mampu menjadi motivator bagi mahasiswa, antusias dan terkesan tidak sekedar menjalankan tugas mengajar.

Hambatan dalam proses mendapatkan role model adalah keterbatasan waktu interaksi. Mahasiswa tingkat sarjana lebih banyak mengidentifikasi dosen sebagai role model dalam mengajar, mereka belum banyak melihat langsung dosen dalam perannya sebagai dokter dan berinteraksi dengan pasien. Mahasiswa mendapatkan role model dosen sebagai dokter ketika mereka memasuki tahap pendidikan klinik. Selain perlu mendapatkan gambaran praktik klinik dari role model, mahasiswa juga memerlukan interaksi dengan role model dalam kehidupan seharihari sebagai seorang dewasa yang menjalani praktik, bukan sekedar interaksi dalam kelas atau proses instruksional. ${ }^{6}$

Sebenarnya, karakter role model dapat diidentifikasi tidak hanya dari dosen ataupun yang dijumpai sehari-hari. Role model juga bisa didapatkan dari cerita atau sejarah tokoh-tokoh kedokteran.Tokohtokoh kedokteran yang dikenal dalam sejarah 
maupun terkenal di masyarakat lokal juga dapat dikenalkan ke mahasiswa sebagai sumber inspirasi dan panutan. Dalam hal konstruksi identitas, Wenger $^{6}$ menekankan desain pendidikan yang memaksimalkan interaksi antar generasi, sehingga dapat mensosialisasikan sejarah praktik komunitas tersebut. Inilah pentingnya berbagi cerita dan sejarah antar generasi, sebagai langkah sosialisasi profesi dan transfer nilai. Sayangnya mahasiswa mengenal tokoh kedokteran hanya pada masa ospek atau dari pendidikan sebelumnya.

Media seperti buku, komik, novel dan film juga menyajikan karakter-karakter dokter yang dapat diidentifikasi sebagai karakter dokter yang baik. Banyak nilai-nilai yang diangkat dalam media, yang sebenarnya sangat penting diketahui sebagai dokter, namun tidak tersampaikan dalam kurikulum. Sebagai contoh, sifat altruis dan kegigihan dokter yang harus praktik di daerah sangat terpencil yang didapatkan dari membaca buku pengalaman dokter. Studi dari Green ${ }^{15}$ mengindikasikan adanya pengaruh membaca, mengkritisi komik dan kemudian membuat sendiri komik berlatar belakang kedokteran dalam membentuk identitas profesional mahasiswa kedokteran. Film juga menyajikan kehidupan dokter lengkap dengan konflik kerja maupun pribadi seorang dokter. Film merupakan sumber yang kaya dengan gambaran profesional dan dapat menjadi sumber pembelajaran sepanjang hayat yang mungkin lebih kuat, bertahan sepanjang hayat dibandingkan pendidikan formal. ${ }^{16}$

Selain memiliki kelebihan, media juga menyajikan kehidupan dokter dengan berbagai kelemahan. Film mampu memberikan gambaran yang menarik tentang konflik dan karakter, namun memiliki kelemahan dalam hal akurasi dalam praktik klinik. ${ }^{17}$ Film seringkali mendramatisir suatu keadaan dan tidak memberikan gambaran yang betul-betul tepat sesuai dengan kenyataan. Hal inilah pentingnya analisis, refleksi dan kritik terhadap film. ${ }^{17,18}$ Beberapa sumber memaparkan kehidupan mahasiswa koas lengkap dengan tekanan dan permasalahannya baik dengan pasien maupun dengan dosen dan lingkungan klinik yang dibalut dalam cerita humor. Seperti halnya film, cerita ini kadang mendramatisir suatu situasi. Inilah pentingnya telaah, analisis atau refleksi terhadap isi buku, cerita, ataupun film.
Mahasiswa seringkali terpapar nilai-nilai yang tidak ideal dalam lingkungan klinik..$^{10}$ Mahasiswa menjumpai hal-hal yang tidak sesuai dengan yang diajarkan dalam pendidikan formal. Karakterkarakter yang mahasiswa temukan dari cerita nyata maupun fiksi dapat menjadi pelengkap bahkan menjadi bahan refleksi mahasiswa untuk mencari karakter ideal yang mungkin tidak didapatkan dari lingkungan klinik nyata yang sehari-hari mereka jumpai. Kurikulum dapat membantu memfasilitasi mahasiswa untuk mengenal berbagai karakter profesional melalui sejarah, telaah buku, maupun film sejak tahun awal mahasiswa. Tokoh-tokoh lokal dapat dikenalkan bahkan dihadirkan, sehingga mahasiswa mendapatkan gambaran sosok dokter profesional sejak awal masa pendidikan.

Penelitian ini dapat memberikan gambaran tentang cara-cara mahasiswa untuk mendapatkan gambaran tentang profesi dokter. Hasil penelitian ini menunjukkan bahwa gambaran tentang dokter dapat diperoleh dari peran aktif mahasiswa untuk mengeksplor profesi dokter dari berbagai media maupun sumber lain. Mengingat pentingnya gambaran tersebut, fakultas perlu mendukung dengan menyediakan program-program pembelajaran yang kontekstual, memudahkan transfer nilai profesional melalui interaksi antargenerasi, buku, cerita sejarah, atau program lainnya.Konsep imajinasi juga tidak berhenti pada proses mendapatkan gambaran tentang profesi dokter. Untuk dapat mengorientasikan diri dalam profesi dokter, masih diperlukan langkah refleksi dan usaha untuk mengeksplorasi kembali diri dan lingkungannya. Penelitian selanjutnya dapat melakukan eksplorasi langkah-langkah fakultas untuk menyiapkan mahasiswanya dalam hal memberikan gambaran yang cukup tentang profesi dokter. Selain itu, dapat dilakukan penelitian eksperimental untuk melihat pengaruh berbagai media bertemakan kedokteran dalam membentuk identitas profesional. 


\section{KESIMPULAN}

Gambaran tentang profesi dokter didapatkan dari kurikulum pembelajaran dalam pendidikan dokter maupun dari luar kurikulum. Kurikulum formal memfasilitasi mahasiswa mendapatkan gambaran tentang lingkungan kerja dan cara kerja profesi dokter. Meskipun gambaran tentang nilai-nilai profesional ditentukan dari kurikulum tersembunyi, kurikulum formal dapat memfasilitasi dengan menyediakan program yang membuka interaksi dengan tokoh dokter antar generasi. Telaah dan analisis terhadap cerita nyata dan fiksi yang dibaca atau dilihat dapat menjadi sarana untuk mendapatkan imajinasi tentang dokter. Kurikulum perlu memfasilitasi terbentuknya gambaran dokter profesional sejak dini pada mahasiswa kedokteran. Selanjutnya, seluruh sumber gambaran tersebut menjadi bekal bagi mahasiswa untuk dapat mengorientasikan dirinya dalam lingkungan profesi.

\section{DEKLARASI KEPENTINGAN}

Artikel ini adalah bagian dari hasil disertasi pengarang pertama. Pengarang bertanggung jawab atas isi dan penulisan artikel ini. Adapun kontributor artike ini adalah:

dr. Yoga Pamungkas Susani, M.Med.Ed. adalah pengarang pertama yang melakukan penelitian sekaligus menulis naskah publikasi ini.

dr. Gandes Retno Rahayu, M.Med.Ed., Ph.D.; dr. Rossi Sanusi, M.PA., Ph.D.; \& Dra. Yayi Suryo Prabandari, M. Si., Ph.D. adalah pembimbing (ko-promotor) dalam perencanaan, pelaksanaan penelitian, hingga pelaporan hasil penelitian serta penulisan naskah publikasi ini.

Prof. dr. Harsono, Sp.S (K) adalah pembimbing utama (promotor) dalam perencanaan, pelaksanaan penelitian, hingga pelaporan hasil penelitian dan penulisan naskah publikasi ini.

\section{DAFTAR PUSTAKA}

1. Bleakley A, Bligh J, Browne J. Medical education for the future, identity, power and location. New York: Springer; 2011.
2. Hilton S.R. \& Slotnick HB. Proto-professionalism: how professionalisation occurs across the continuum of medical education. Med Educ. 2005;39:58-65.

3. Forsythe GB. Identity Development in Professional Education. Acad Med. 2005;80, No. 10:S112-7.

4. Monrouxe L V. Identity, identification and medical education: why should we care? Med Educ. 2010;44:40-9.

5. Hogg MA. \& Terry DJ. Social Identity and SelfCategorization Processes in Organizational Contexts. Acad Manag Rev. 2000;25(1):121-40.

6. Wenger E. Communities of Practice: Learning, Meaning, and Identity. New York: Cambridge University Press; 1998.

7. Wenger E. Communities of Practice : Learning as a Social System. 2008;(June 1998):1-10.

8. Hafferty FW, Franks R. The hidden curriculum, ethics teaching, and the structure of medical education. Acad Med. 1994;69(11):861-71.

9. Hafferty FW. Beyond curriculum reform: confronting medicine's hidden curriculum. Acad Med. 1998;73(4):403-7.

10. Inui TS. A Flag in the Wind: Educating for Professionalism in Medicine. Washington, DC; 2003.

11. Coulehan J. Today's Profesionalism: Engaging the Mind but Not the Heart. Acad Med. 2005;80:892-8.

12. Huddle T. Teaching Professionalism: Is Medical Morality a Competency? Acad Med. 2005;80, issue:885-91.

13. Baingana R, Nakasujja N, Galukande M, Omona K, Mafigiri DK, Sewankambo NK. Learning health professionalism at Makerere University: an exploratory study amongst undergraduate students. BMC Med Educ. 2010;10: 76.

14. Mann K V. Learning and Teaching in Professional Character Development. In: Kenny N, Shelton W, editors. Advances in Bioethics Lost Virtue: Professional Character Development of Medical Education. Volume 10. Amsterdam: Elsevier Ltd; 2006. p. 145-83.

15. Green MJ. Comics and Medicine. Acad Med [Internet]. 2015;90(6): 1. Available from: http:// content.wkhealth.com/PTLP: landingpage\&an= 00001888-900000000-98816

16. Bleakley A. Becoming a Medical Professional. In: Scanlon L, editor. "Becoming" a Professional an Interdisciplinary Analysis of Professional Learning. London: Springer; 2011. p. 129-52. 
17. Scanlon L. White Coats, Handmaidens and Warrior Chiefs: The Role of Filmic Representations in Becoming a Professional. In: Scanlon L, editor. "Becoming" a Professional an Interdisciplinary Analysis of Professional Learning. London: Springer Science; 2011. p. 109-25.
18. Goodman K. Imagining doctors: medical students and the TV medical drama. Am Med Assoc J Ethics. 2007;9(3):182-7. 